Article

\title{
Study and Characterization of Environmental Deposition on Marble and Surrogate Substrates at a Monumental Heritage Site
}

\author{
Paola Fermo $^{1, *}$, Sara Goidanich ${ }^{2}$, Valeria Comite ${ }^{1}$, Lucia Toniolo ${ }^{2}$ and Davide Gulotta ${ }^{2}$ (D) \\ 1 Dipartimento di Chimica, University of Milan, Via Golgi 19, 20133 Milano, Italy; valeria.comite@unimi.it \\ 2 Dipartimento di Chimica, Materiali e Ingegneria Chimica “Giulio Natta”, Politecnico di Milano, \\ Piazza Leonardo da Vinci 32, 20133 Milano, Italy; sara.goidanich@polimi.it (S.G.); \\ lucia.toniolo@polimi.it (L.T.); davide.gulotta@polimi.it (D.G.) \\ * Correspondence: paola.fermo@unimi.it; Tel.: +39-338-414-8490
}

Received: 7 August 2018; Accepted: 10 September 2018; Published: 14 September 2018

\begin{abstract}
In this study, the results of the field exposure activity conducted between 2014 and 2017 on the façade of the Milano cathedral (Italy) are reported. The main research aim was to characterize environmental deposition in real exposure conditions and for this purpose, both stone substrates (Candoglia marble) and surrogate substrates (quartz fibre filters) were exposed on the cathedral façade in two sites at different heights. A complete chemical characterization has been performed on quartz filters and marble substrates, i.e., quantification of the deposited aerosol particulate matter (PM) and of the main ions. On quartz filters, the carbonaceous component of deposits was also investigated, as well as the color change induced by soiling, by means of colorimetric measurements. The combined approach exploiting marble and surrogate substrates seems to be a suitable monitoring strategy, although some aspects should be taken into account. In particular, differences in the deposits composition have been highlighted mainly depending on the type of substrate. The environmental data related to atmospheric pollution in Milan for the same period have also been considered but no direct correlations were found between some atmospheric precursors and their related ions in solid deposits.
\end{abstract}

Keywords: depositions on marble; cultural heritage; exposure tests

\section{Introduction}

The stone surfaces of the cultural and architectural heritage exposed to the outdoors are subjected to the long-term interaction with the atmospheric pollutants, deriving from both natural and anthropogenic sources [1]. In urban polluted conditions, gas and solid pollutants form complex and multi-component mixtures, which are known to be particularly harmful towards carbonatic substrates [2-5]. The most relevant deterioration processes resulting from such interaction have been extensively studied, in particular, with respect to their chemical reactivity towards the stone substrates [5-8] and to the aesthetic alteration of the exposed surfaces they can trigger, mainly in the form of soiling [9-11].

Efforts have been made to characterize the actual contribution of atmospheric pollutants to damage, in terms of evolution of the deterioration patterns and kinetics of the chemical alteration processes, and monitoring of atmospheric aerosols has also been proposed as a preventive conservation approach for heritage surfaces [12].

This is a particularly challenging task, given the high number of parameters involved, their variability in time and the impact of the currently changing climate scenario. Moreover, considering 
the specific issue of soiling of the architectural surfaces, deposition rate cannot be estimated only from ambient concentration of pollutants [13] as the inherent features of the substrates, their orientation and the microclimatic aspect are key factors governing the phenomenon. For all these reasons, site exposure tests represent a widely exploited approach to study the response of stone substrates to environmental pressure in actual exposure conditions [10,11,14-17].

In the present work, the results of the field exposure activity conducted between 2014 and 2017 on the main façade of the Milano cathedral are reported. The research was aimed to characterize the environmental deposition in real exposure conditions under the chemical point of view, with a focus on the relationship between atmospheric pollutants and deposition of solid pollutants on the highly valuable architectural surfaces. For this purpose, a specific exposure protocol was designed, combining stone and surrogate substrates. Such approach allowed the comparison between deposition on marble specimens, representative of the actual façade materials, and surrogate substrates provided by quartz fiber filters, which allowed a complete chemical characterization of the particulate matter (PM). The local environmental data corresponding to the two site exposure periods and the historic trends of the main pollutants of Milano city center were also considered.

The Milano cathedral is a remarkable asset of the Italian architectural heritage. Its main façade is entirely made of Candoglia marble, a coarse-grained metamorphic stone with a peculiar white to pink color and presence of grey veins. The façade is cladded by flat slabs and richly decorated with frames, low and high reliefs, architectural elements and sculptures realized between the XVI and XIX centuries. Due to the particularly aggressive exposure conditions of the Milano city center, which caused dramatic damages to the marble surfaces over the years, the façade has been subjected to several extensive conservative intervention during the XX century. The most recent intervention was carried out between 2003 and 2008 and included the general cleaning of all the marble elements, corresponding to a total treated surface of about 10,500 square meters [18]. The results of the field exposure activity here reported are part of the overall monitoring and diagnostic project, supporting the definition of preventive conservation guidelines for the façade.

\section{Materials and Methods}

Quartz fiber filters (QM-A Whatman, without binder) and Candoglia marble specimens were exposed on-site in outdoor conditions sheltered from direct rain-wash on the façade. Two different exposure sites were identified at $19.70 \mathrm{~m}$ (site 1) and $9.40 \mathrm{~m}$ (site 2) from the ground level (Figure 1). Site 1 corresponds to the central balcony of the façade. Specimens were exposed on a stainless-steel rack, provided with a PVC roof panel to protect them from the direct rain. All specimens were exposed with a horizontal orientation. Site 2 is located in the south pillar, above the left portal of the façade, exploiting the horizontal surface of the protruding lintel. An overhanging curved tympanum provided shelter from the rain. Over the course of the site exposure, site 2 proved to be particularly protected from most of the rain, whereas in case of particularly intense rain events, some specimens exposed on site 1 were partly in contact with liquid water and therefore were discarded (see Table 1 for the complete list of the analyzed filters). Quartz filters were kept in place by means of plastic containers sealed to the rack or to the lintel surface and leaving the upper surface completely exposed to deposition; marble specimens were just placed on the racks or on the architectural surface, exploiting their inherent higher weight to keep them in a stable position. 


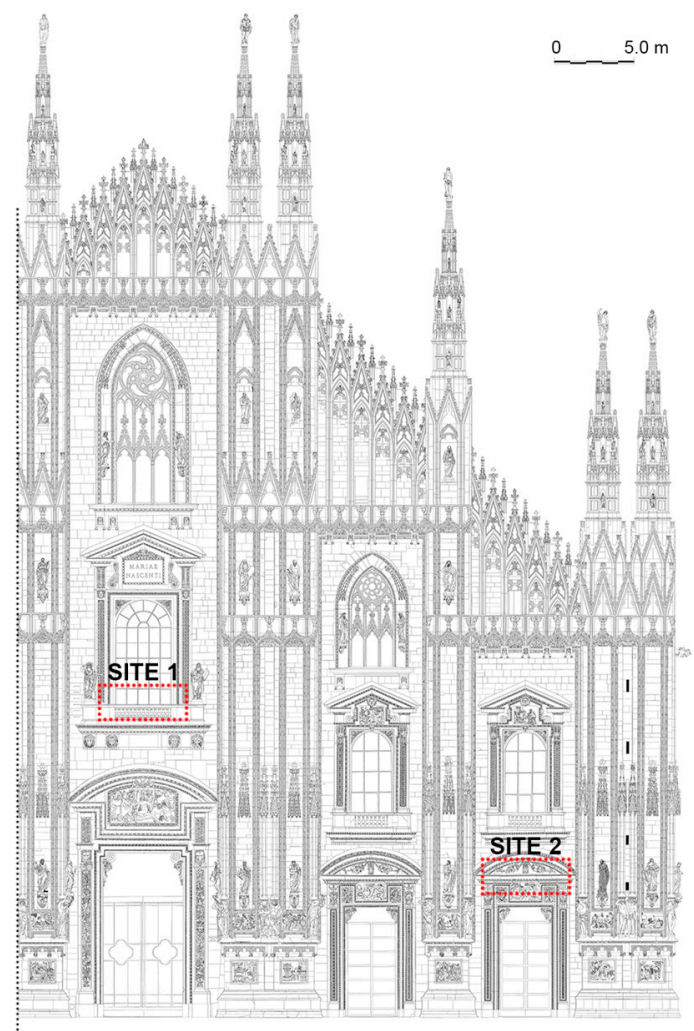

Figure 1. Scheme of the façade of the Milano cathedral (courtesy of Veneranda Fabbrica del Duomo di Milano) indicating the location of the exposure sites.

Table 1. List of quartz fiber filters and marble specimens exposed on the Duomo façade in two sites at different height for two sampling periods.

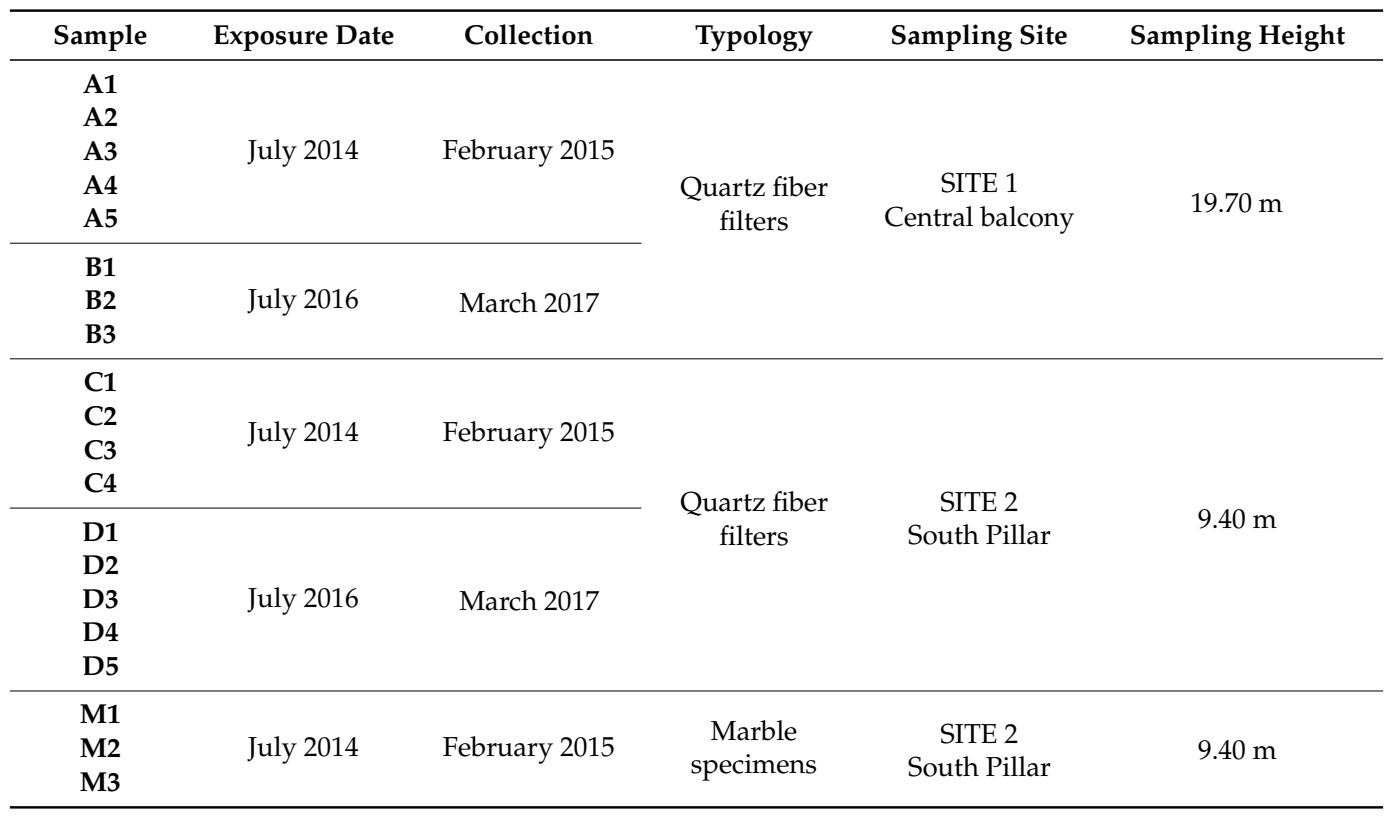

Quartz filters were pre-conditioned at room temperature in a desiccator for $48 \mathrm{~h}$ before weighing; after field exposure, they were again conditioned for $48 \mathrm{~h}$ and weighed to determine the deposited powder. 
Stone specimens were made of fresh Candoglia marble and were cut into $5 \times 5 \times 2 \mathrm{~cm}^{3}$ size. Candoglia marble is a coarse-grained and highly compact marble, with an average porosity below $1 \%$. Its main mineralogical component is calcite, with quartz, pyrite and mica as accessory mineral [19].

The stone substrates were polished with $180 \mathrm{SiC}$ grinding paper to obtain standard reference surfaces (i.e., removal of uneven traces of the cutting procedures) and then washed in deionized water to remove all residues prior to exposure [20].

Two 6-month site exposure were performed in the period July 2014-February 2015 and July 2016-March 2017. A set composed of 5 quartz filters was exposed on sites 1 and 2 for each period, whereas all stone specimens belongs to the first period of exposure (Table 1). At the end of the exposure period, specimens and filters were collected from the sites, stored in sealed plastic containers and transported to the laboratory. A dry removal of the atmospheric deposit from the stone specimens was conducted by means of a stainless-steel scalpel. Particular attention was paid in order to limit the contribution from the stone substrate, i.e., detachment of marble micro-fragments, by working with very mild mechanical action to effectively remove the deposit.

The color change of quartz filters induced by soiling was evaluated by means of colorimetric measurements using a Konica Minolta CM-600D VIS-light spectrophotometer with a D65 illuminant at $8^{\circ}$, wavelength range between $400 \mathrm{~nm}$ and $700 \mathrm{~nm}$. At least 3 measurements were conducted on each filter before and after the site exposure. The average data were elaborated according to the CIE $L^{*} \mathrm{a}^{*} \mathrm{~b}^{*}$ standard color system [21]: the variations in lightness and in the saturation of the ${ }^{*} b$ coordinate were calculated respectively as $\Delta \mathrm{L}^{*}=\mathrm{L}^{*}$ after exposure $-\mathrm{L}^{*}$ before exposure, and $\Delta \mathrm{b}^{*}=\mathrm{b}^{*}$ after exposure $-\mathrm{b}^{*}$ before exposure.

A chemical characterization was carried out on both atmospheric deposits removed from the marble specimens and pollutants deposits on quartz fibre filters. Ionic chromatography (IC) was employed for the quantification of the main cationic $\left(\mathrm{Na}^{+}, \mathrm{K}^{+}, \mathrm{Ca}^{2+}\right.$ and $\left.\mathrm{Mg}^{2+}\right)$ and anionic $\left(\mathrm{NO}_{2}{ }^{-}\right.$, $\mathrm{NO}_{3}{ }^{-}, \mathrm{SO}_{4}{ }^{2-}$ and $\mathrm{Cl}^{-}$) species by using an ICS-1000 instrument equipped with a conductivity system detector and working with self-regenerating suppressors systems. The solutions suitable for the analysis were prepared according to procedures previously reported [22-24]. Samples of deposits on marble surfaces were characterized by Fourier Transform Infrared Spectroscopy (FTIR) using a Thermo Nicolet 6700 FTIR spectrometer with a DTGS detector in the spectral range $4000-400 \mathrm{~cm}^{-1}$. Samples were prepared in $\mathrm{KBr}$ dispersion.

Carbonaceous fraction analysis, i.e., determination of organic carbon $(\mathrm{OC})$ and elemental carbon (EC), has been carried out on filters following the methodology conventionally used for their determination in the aerosol particulate matter $[25,26]$.

The environmental trends of the main pollutants of Milano city center (namely $\mathrm{SO}_{2}, \mathrm{NO}_{\mathrm{x}}$ and $\mathrm{PM}_{10}$ ) have been analyzed to better understand the deposits on both stone and quartz substrates. Environmental data were acquired from the local environmental protection agency (ARPA Lombardia, www.arpalombardia.it) and belong to two sampling sites in the city center, both located within a $500 \mathrm{~m}$ linear distance from the façade of the cathedral.

\section{Results and Discussion}

\subsection{Environmental Data and Historic Trends of Some Pollutants of Milano City Center}

The presence of sulphur dioxide in the air is due to the combustion of sulphur-containing fossil fuels used mostly for the production of electricity or heating; in urban environment, such as Milan, traces may also be present in automotive emissions that use low refined fuels. In nature, the main source of $\mathrm{SO}_{2}$ is volcanic activity. Sulphur dioxide is therefore a primary pollutant emitted mostly at the "chimney" level. Moreover, Milan is also subjected to additional stationary sources of $\mathrm{SO}_{2}$, such as an industrial area, including an oil refinery and a carbon black manufacture sited $40 \mathrm{~km}$ West and a refinery sited $50 \mathrm{~km}$ South-West of the city. Such sources are sufficiently close to Milan to impact the local atmosphere [27]. From 1970, the technology has made available low-sulphur fuels, the use of 
which has been imposed by the legislation. Moreover, thanks to the transition of the heating systems to natural gas, the concentrations registered for Milan in the last few years have been further reduced. If the entire data set available for $\mathrm{SO}_{2}$ is considered [www.arpalombardia.it], starting from 1968, it can be observed that the values have considerably decreased from concentrations of more than $1000 \mu \mathrm{g} / \mathrm{m}^{3}$ to much lower values. In particular, in Figure 2, the trend of concentration of the most recent period (2000-2018) is shown.

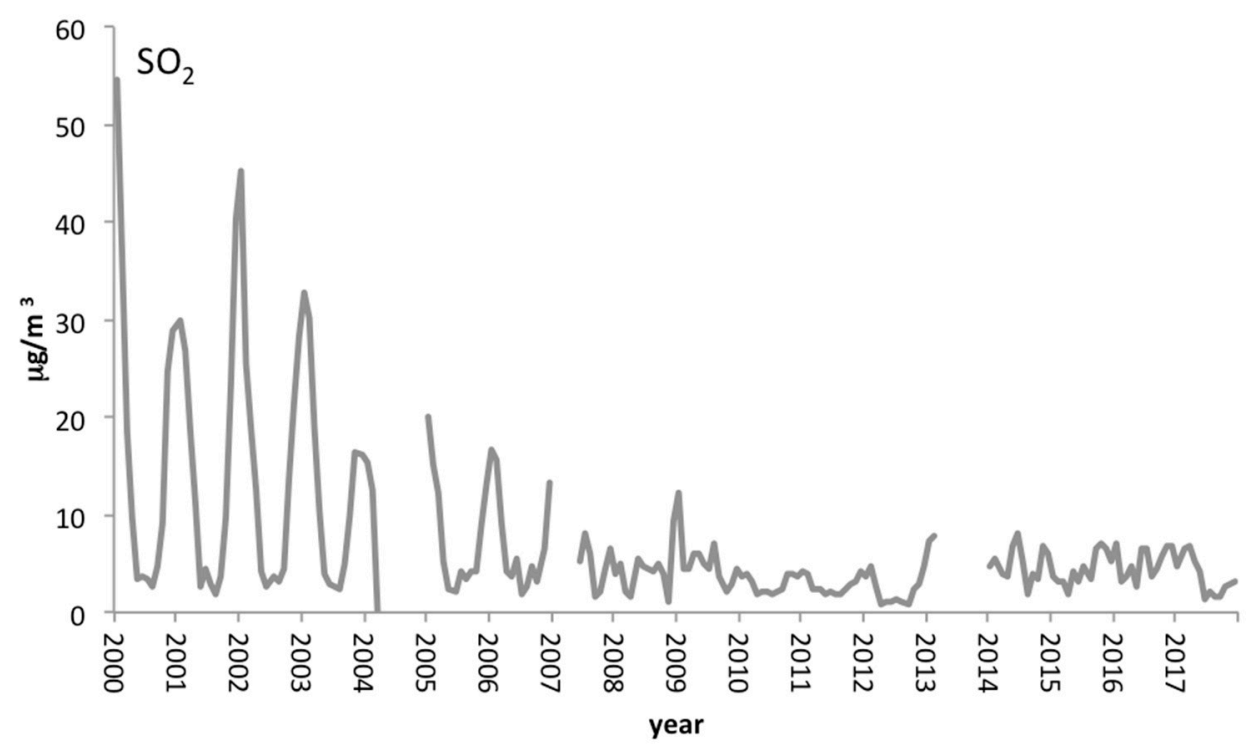

Figure 2. $\mathrm{SO}_{2}$ concentrations trend registered for Milan monitoring sites (data from ARPA Lombardia) from 2000 until today.

The air concentrations are far below the limits set by Legislative Decree 155/2010 $\left(125 \mu \mathrm{g} / \mathrm{m}^{3}\right.$ as daily value). Overall, $\mathrm{SO}_{2}$ concentrations in Milan are not far from the values observed for other European cities [27].

It is worth noting that in spite of the $\mathrm{SO}_{2}$ reduction in atmosphere and of the clear improvement of the emission scenario, the presence of sulphate still dominates the chemical composition of the deposits in urban environments [28,29]. This is also confirmed by the results of the chemical characterization of deposits on both filters and marble specimens (as it will be detailed in the next paragraph) after site exposure. This fact could be related to a higher stability and/or a preferential accumulation of sulphate species.

In Figure 3, the trend of $\mathrm{NO}_{\mathrm{x}}$ emission during the period of interest for the field exposure tests (2014-2017) has been reported, together with $\mathrm{SO}_{2}$ concentrations for the same periods. The annual trend of nitrogen dioxide concentrations shows a marked seasonal dependence, with higher values in the winter period, due to both worst dispersive capacity of the atmosphere in the colder months and presence of additional sources, such as domestic heating. 


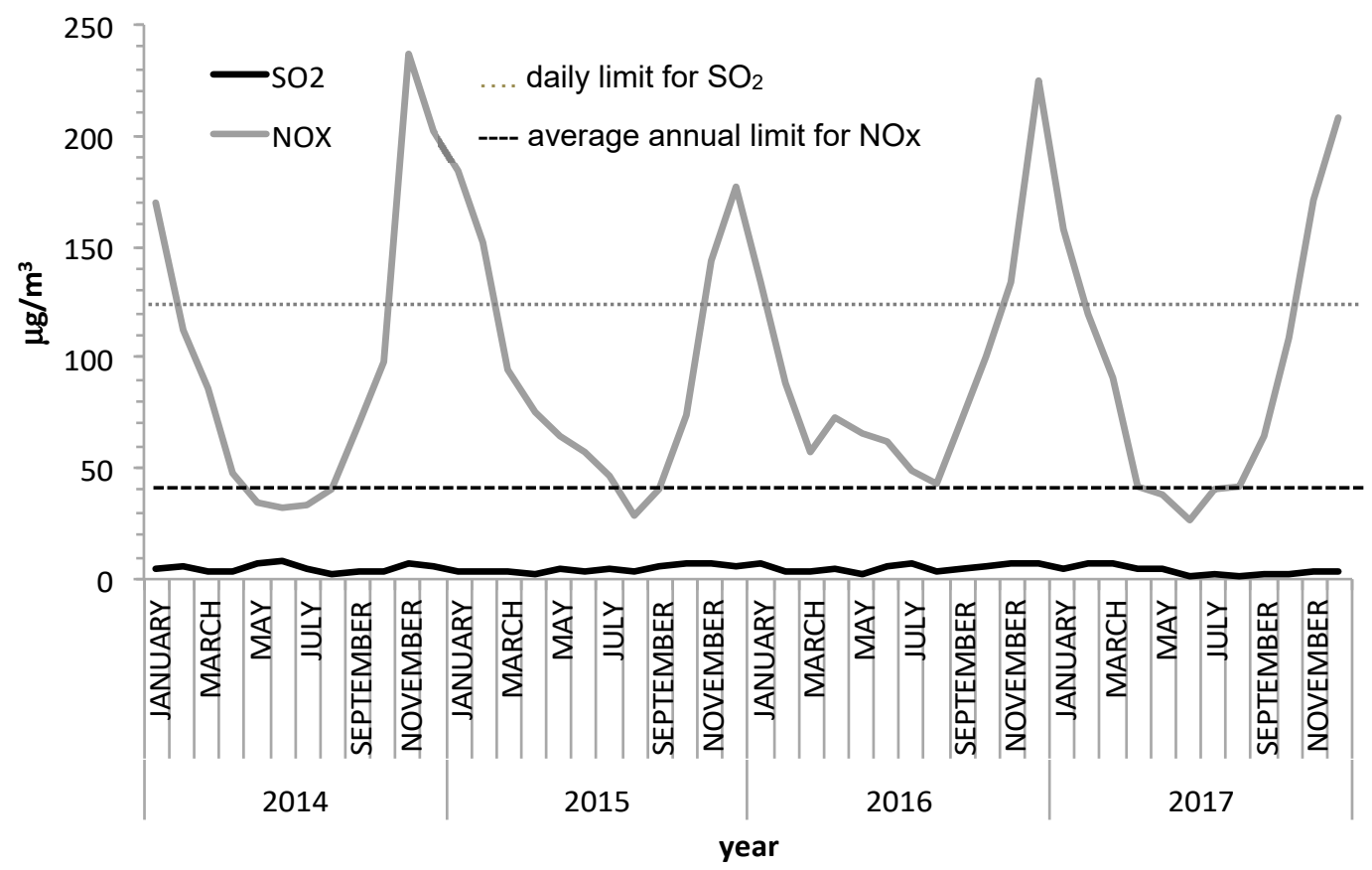

Figure 3. $\mathrm{NO}_{\mathrm{x}}$ and $\mathrm{SO}_{2}$ concentrations trend registered for Milan monitoring sites (data from ARPA Lombardia) during the period of interest for the exposure field tests (2014-2017); daily limit and average annual limit respectively for $\mathrm{SO}_{2}$ and $\mathrm{NO}_{x}$ (according to D. Lgs. 155/2010) have been reported.

In Figure 4, $\mathrm{PM}_{10}$ concentration trend is reported starting from 2002. The same series is not available for $\mathrm{PM}_{2.5}$ (that the environmental protection agency started to measure only more recently) but it is worth noting that in Milan $\mathrm{PM}_{2.5} / \mathrm{PM}_{10}$ ratio is often higher than 0.7 and sometimes almost close to 1, thus indicating that PM10 fraction is mainly composed by $\mathrm{PM}_{2.5}$. The analysis of the data collected in the period 2014-2016 [30-32] confirms that particulate matter, for which there are numerous and repeated exceeding of the limits (Figure 4), is one of the most critical parameters for air pollution. It has also a direct impact on cultural heritage surfaces since it is involved in adverse effects such as soiling and sulphation processes $[4,6]$. More specifically the finer fraction, i.e., $\mathrm{PM}_{2.5}$, is involved on both soiling and gypsum nucleation.

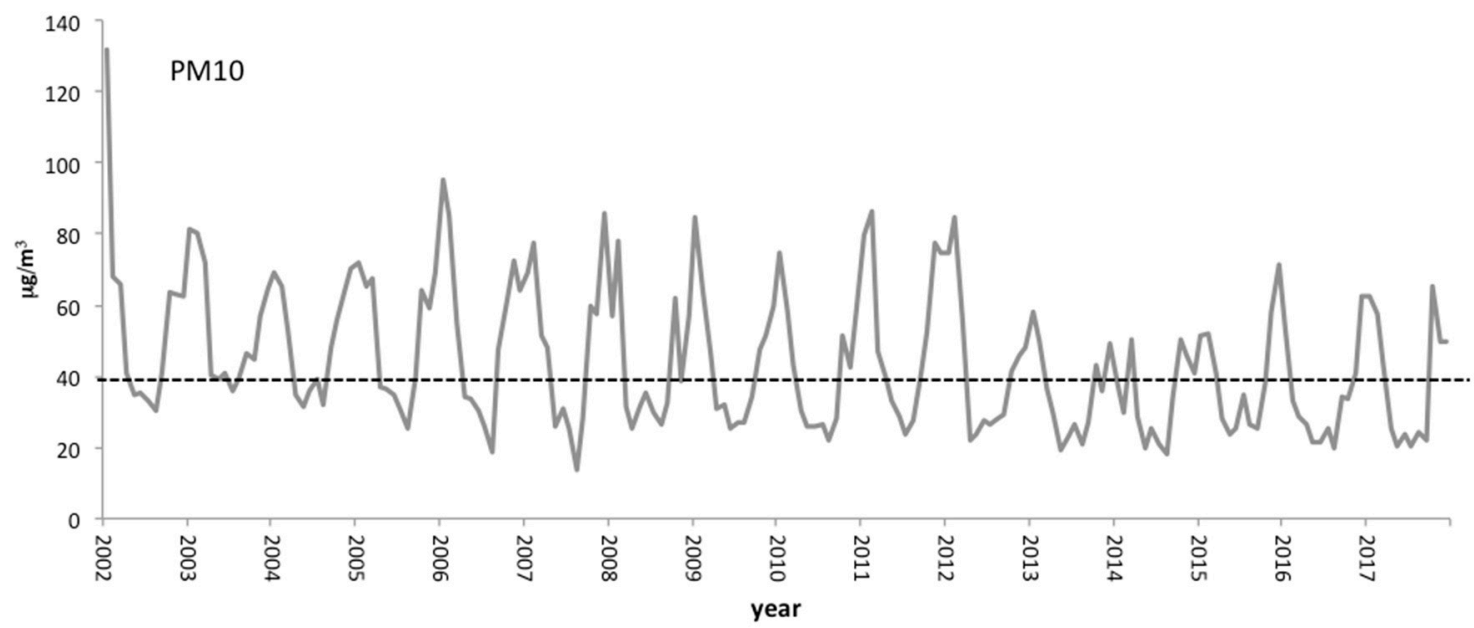

Figure 4. Particulate matter $(\mathrm{PM})_{10}$ concentrations trend registered for Milan monitoring sites (data from ARPA Lombardia); average annual limit (according to D. Lgs. 155/2010) has been reported (dotted line). 
Examining the time series with a particular attention to the last decade, it can be noted that $\mathrm{PM}_{10}$ concentrations and the number of days of exceeding of the limit on the daily average are appreciably decreased [30-32]. Beyond the meteorological variability, the environmental policies implemented at local, regional and national level contributed to this result, and perhaps, although difficult to quantify, a possible effect linked to the decrease in consumption due to the economic crisis of recent years.

\subsection{Characterization of Deposits on Marble and Surrogate Substrates}

A preliminary FTIR (Fourier Transform Infrared Spectroscopy) characterization has been carried to assess the general composition of the deposits on marble substrates. FTIR analysis of samples of deposits from specimens exposed in site 2 indicates a prevailing calcitic composition (a representative FTIR spectrum is reported in Figure 5). Calcite is identified by the characteristic absorption peaks at 1425,875 and $715 \mathrm{~cm}^{-1}$. A significant presence of calcium sulphate, as gypsum, can also be observed (peals at 3541-3407, 1620, 1143-1115 and 670-602 $\mathrm{cm}^{-1}$ ), together with nitrates (peak at $1385 \mathrm{~cm}^{-1}$ ). Peak at $1036 \mathrm{~cm}^{-1}$ (stretching mode of the Si-O bond) and the doublet at $797-779 \mathrm{~cm}^{-1}$ are due to the silicatic fraction of the deposit and to the presence of crystalline quartz, respectively. Moreover, the presence of organic compounds within the deposit is also indicated by the absorption peaks in the $2850-2920 \mathrm{~cm}^{-1}$ region.

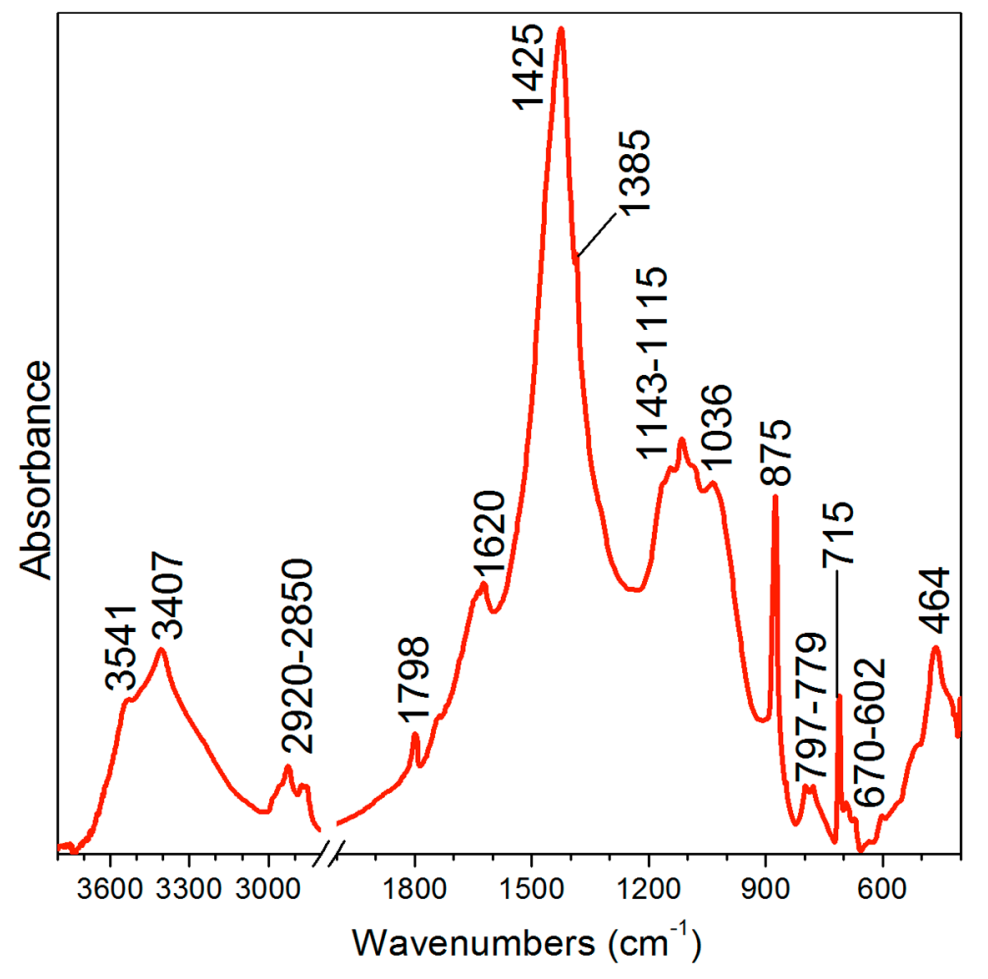

Figure 5. FTIR characterization of a representative deposit on stone specimen (site 2).

The main ionic species determined for each quartz filter and for the deposits on marble specimens, together with the average values for each site and for the two exposure periods, are reported in Table 2 . In Figures 6 and 7 the average concentrations of anions and cations for quartz filter are shown, while in Figure 8 anions and cations average concentrations determined in the deposits on marble are reported. It has to be pointed out that the ionic composition of deposits from marble might be slightly affected by a contribution belonging to the substrate itself, although sampling was performed by mild and controlled mechanical actions. 
Table 2. Main ionic species determined on quartz fiber filters and powder deposits on marble specimens exposed in the two sites on the Duomo façade for two periods.

\begin{tabular}{|c|c|c|c|c|c|c|c|c|c|}
\hline & & \multicolumn{8}{|c|}{$\mu \mathrm{g} / \mathrm{cm}^{2}$} \\
\hline & & \multicolumn{3}{|c|}{ Anions } & \multicolumn{5}{|c|}{ Cations } \\
\hline & & $\mathrm{Cl}^{-}$ & $\mathrm{NO}_{3}{ }^{-}$ & $\mathrm{SO}_{4}{ }^{2-}$ & $\mathrm{Na}^{+}$ & $\mathrm{NH}_{4}{ }^{+}$ & $\mathbf{K}^{+}$ & $\mathrm{Mg}^{2+}$ & $\mathrm{Ca}^{2+}$ \\
\hline \multirow{14}{*}{$\begin{array}{l}\text { Site } 1 \text { Central } \\
\text { terrace } 19.70 \mathrm{~m}\end{array}$} & \multicolumn{9}{|c|}{ July 2014-February 2015} \\
\hline & A1 & 7.0 & 19.7 & 28.2 & 7.2 & 1.1 & 3.0 & 1.9 & 39.0 \\
\hline & A2 & 5.3 & 10.2 & 18.1 & 5.5 & n.a. & 1.4 & 1.3 & 38.1 \\
\hline & A3 & 5.7 & 14.5 & 24.7 & 4.9 & 0.1 & 1.6 & 1.1 & 16.3 \\
\hline & A4 & 5.9 & 15.0 & 26.3 & 4.5 & 0.1 & 1.4 & 1.1 & 15.2 \\
\hline & A5 & 4.7 & 4.8 & 18.5 & 4.0 & 0.1 & 0.9 & 0.7 & 11.5 \\
\hline & Average & 5.7 & 12.9 & 23.1 & 5.2 & 0.3 & 1.7 & 1.2 & 24.0 \\
\hline & Std dev & 0.4 & 2.5 & 2.1 & 0.6 & 0.2 & 0.4 & 0.2 & 6.0 \\
\hline & \multicolumn{9}{|c|}{ July 2016-March 2017} \\
\hline & B1 & 17.6 & 21.9 & 23.0 & 14.9 & 0.4 & 2.7 & n.a & 64.2 \\
\hline & B2 & 17.6 & 6.6 & 20.4 & 13.7 & 0.3 & 1.9 & n.a & 54.5 \\
\hline & B3 & 16.7 & 17.2 & 25.9 & 13.8 & 0.4 & 2.2 & n.a & 58.9 \\
\hline & Average & 17.3 & 15.2 & 23.1 & 14.1 & 0.4 & 2.3 & n.a & 59.2 \\
\hline & Std dev & 0.3 & 4.6 & 1.6 & 0.4 & 0.0 & 0.3 & n.a & 2.8 \\
\hline \multirow{15}{*}{$\begin{array}{c}\text { Site } 2 \text { South Pillar } \\
9.40 \mathrm{~m}\end{array}$} & \multicolumn{9}{|c|}{ July 2014-February 2015} \\
\hline & $\mathrm{C} 1$ & 4.0 & 2.5 & 17.1 & 2.9 & 0.1 & 0.8 & 0.7 & 11.9 \\
\hline & $\mathrm{C} 2$ & 4.3 & 7.2 & 13.6 & 3.0 & 0.1 & 1.1 & 0.8 & 13.6 \\
\hline & $\mathrm{C} 3$ & 3.8 & 6.8 & 11.9 & 2.9 & 0.1 & 0.9 & 0.8 & 14.3 \\
\hline & C4 & 4.1 & 6.7 & 12.3 & 3.2 & 0.1 & 1.0 & 0.8 & 15.0 \\
\hline & Average & 4.0 & 5.8 & 13.7 & 3.0 & 0.1 & 0.9 & 0.8 & 13.7 \\
\hline & Std dev & 0.1 & 1.1 & 1.2 & 0.1 & 0.0 & 0.1 & 0.0 & 0.7 \\
\hline & \multicolumn{9}{|c|}{ July 2016-March 2017} \\
\hline & D1 & 11.8 & 7.0 & 7.8 & 9.7 & 0.4 & 0.9 & n.a & 30.8 \\
\hline & D2 & 15.6 & 7.3 & 8.9 & 11.5 & 0.4 & 1.1 & n.a & 33.1 \\
\hline & D3 & 14.0 & 7.8 & 9.6 & 9.3 & 0.3 & 0.9 & n.a & 34.8 \\
\hline & D4 & 17.3 & 9.0 & 9.7 & 11.0 & 0.3 & 1.0 & n.a & 36.7 \\
\hline & D5 & 15.5 & 6.7 & 9.7 & 11.2 & 0.2 & 1.0 & n.a & 38.2 \\
\hline & Average & 14.9 & 7.5 & 9.1 & 10.5 & 0.3 & 1.0 & n.a & 34.7 \\
\hline & Std dev & 0.9 & 0.4 & 0.4 & 0.4 & 0.0 & 0.0 & n.a & 1.3 \\
\hline \multirow{6}{*}{$\begin{array}{c}\text { Site } 2 \text { South Pillar } \\
9.40 \mathrm{~m}\end{array}$} & \multicolumn{9}{|c|}{ July 2014-February 2015} \\
\hline & M1 & 1.3 & 1.9 & 25.4 & 2.0 & 0.0 & 0.7 & 0.4 & 18.9 \\
\hline & M2 & 1.4 & 2.7 & 23.8 & 1.4 & 0.6 & 0.7 & 0.3 & 17.9 \\
\hline & M3 & 1.2 & 5.9 & 20.6 & 1.2 & n.a & 0.7 & 0.3 & 16.1 \\
\hline & Average & 1.3 & 3.5 & 23.3 & 1.5 & 0.3 & 0.7 & 0.3 & 17.6 \\
\hline & Std dev & 0.1 & 1.2 & 1.4 & 0.3 & 0.2 & 0.0 & 0.0 & 0.8 \\
\hline
\end{tabular}

Sulphate is the anionic species present with the highest concentration in both filters and marble specimens, in accordance with what typically observed for aerosol particulate matter in urban conditions [28,29], with the exception of the filters exposed in site 2 in the second exposure campaign (2016-2017), during which the main anionic species was chloride. It is worth noting that for marble specimens $\mathrm{SO}_{4}{ }^{2-}$ concentration is almost twice the one of the filters. In this context, the contribution of an early stage sulphation process due to the interaction between atmospheric $\mathrm{SO}_{2}$ and the outermost portion of the stone substrate cannot be excluded.

Such process was identified as an important decay mechanism of the façade in the past [33] and can be favored by the specific exposure conditions [2]. Furthermore, the higher sulphate/nitrate ratio found for the marble surfaces with respect to quartz filters is in accordance with what already observed in a previous study [17]. The overall characterization results indicate that the deposits have a significant potential for deterioration of the stone surfaces. In particular, high amount of sulphates, soluble salts and silicatic compounds are typically associated to damage layers in urban conditions [34].

As regards the differences between the two exposure sites, during both periods sulphates are always higher in site 1 with respect to site 2 (Figure 6). The same trend is observable for the other anions. The compositional differences between the two sites are influenced by several factors and are not easy to be explained. In particular, besides the different height, the complex geometry of the 
façade's elements surely plays a role in air circulation [35], together with the presence of urban canyons effects [36], thus affecting particles deposition.

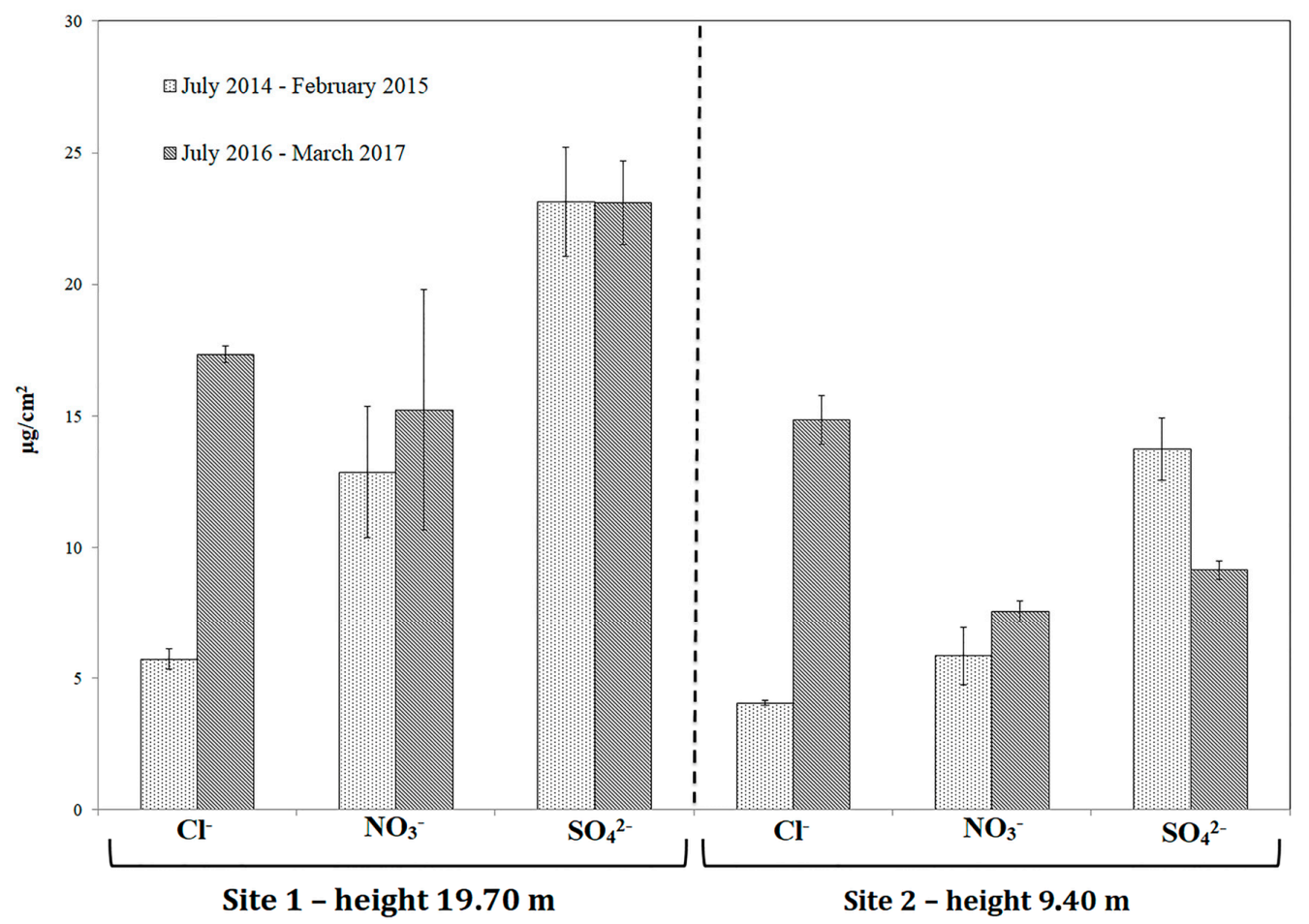

Figure 6. Anions average concentrations determined on the quartz fiber filters exposed in the two sites on the Duomo façade during the two periods.

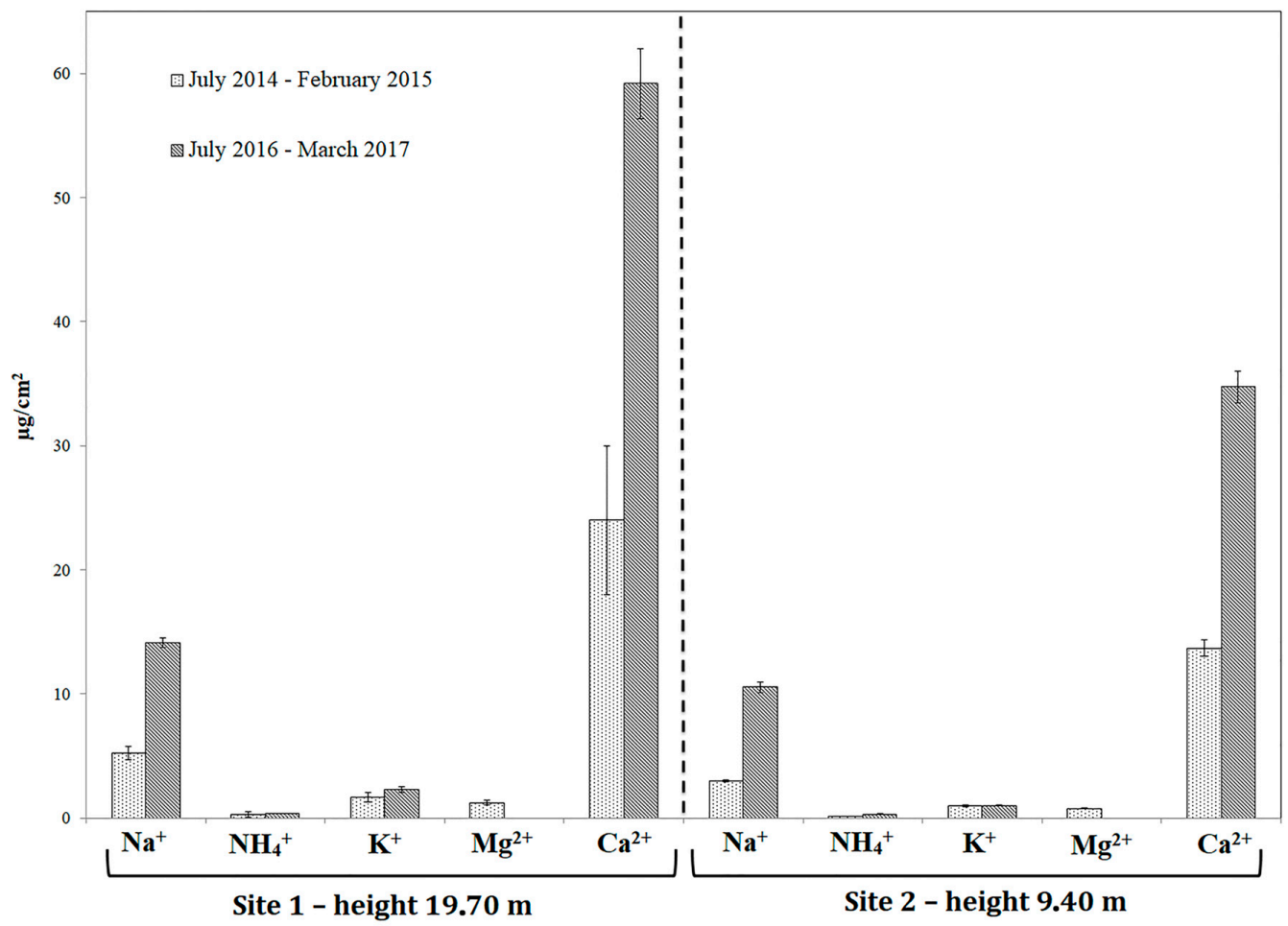

Figure 7. Cations average concentrations determined on the quartz fiber filters exposed in the two sites on the Duomo façade during the two periods. 


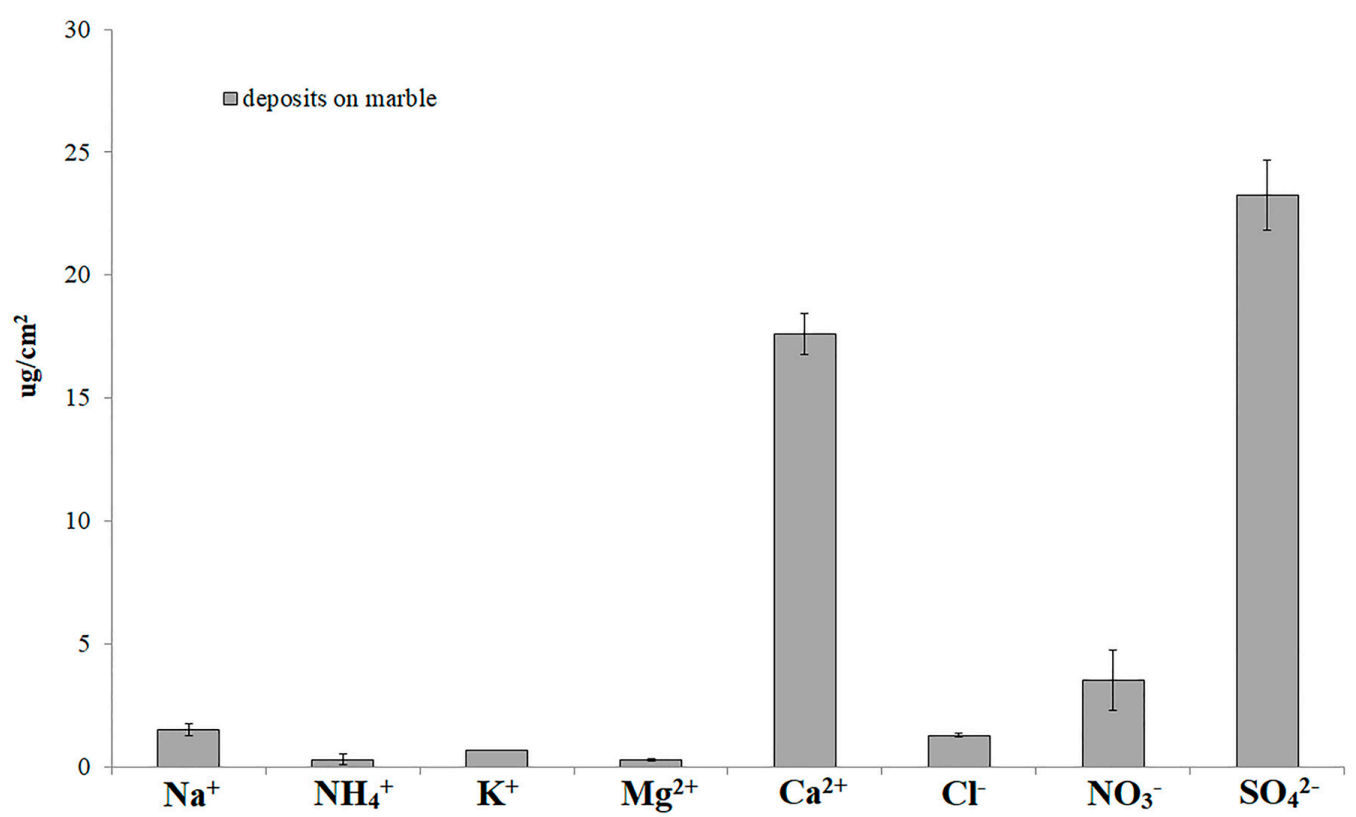

Figure 8. Cations and anions average concentrations determined in the deposits on marble specimens exposed on the Duomo façade during the first period (2014-2015).

In general, a very low concentration of $\mathrm{NH}_{4+}$ was detected upon exposure (Figure 7), while it is known that on filters $\mathrm{SO}_{4}{ }^{2-}$ is typically found as ammonium sulphate [23]. The low concentration detected may be due to the decomposition of such compound. Since sulphate in the aerosol particulate matter could be of both anthropogenic or marine origin, an apportionment between these two sources has been calculated in accordance with what reported in the literature [37-41]. This approach is based on the fact that sulphate of marine origin is present as sodium sulphate and, as a consequence, sulphate of anthropogenic origin (NSS_SO ${ }_{4}{ }^{2-}=$ non-sea salt sulphate) can be calculated from total sulphate by subtracting the contribution from $\mathrm{Na}_{2} \mathrm{SO}_{4}\left(\mathrm{SS}_{-} \mathrm{SO}_{4}{ }^{2-}=\right.$ sea salt sulphate), considering the ratio between these two elements in sea salt. As it can be observed in Figure 9, during the first campaign (2014-2015) the calculated contribution from sea salt is lower with respect to the second campaign (2016-2017) and this is also in accordance with the lower chloride concentrations detected in 2014-2015 (Figure 6).

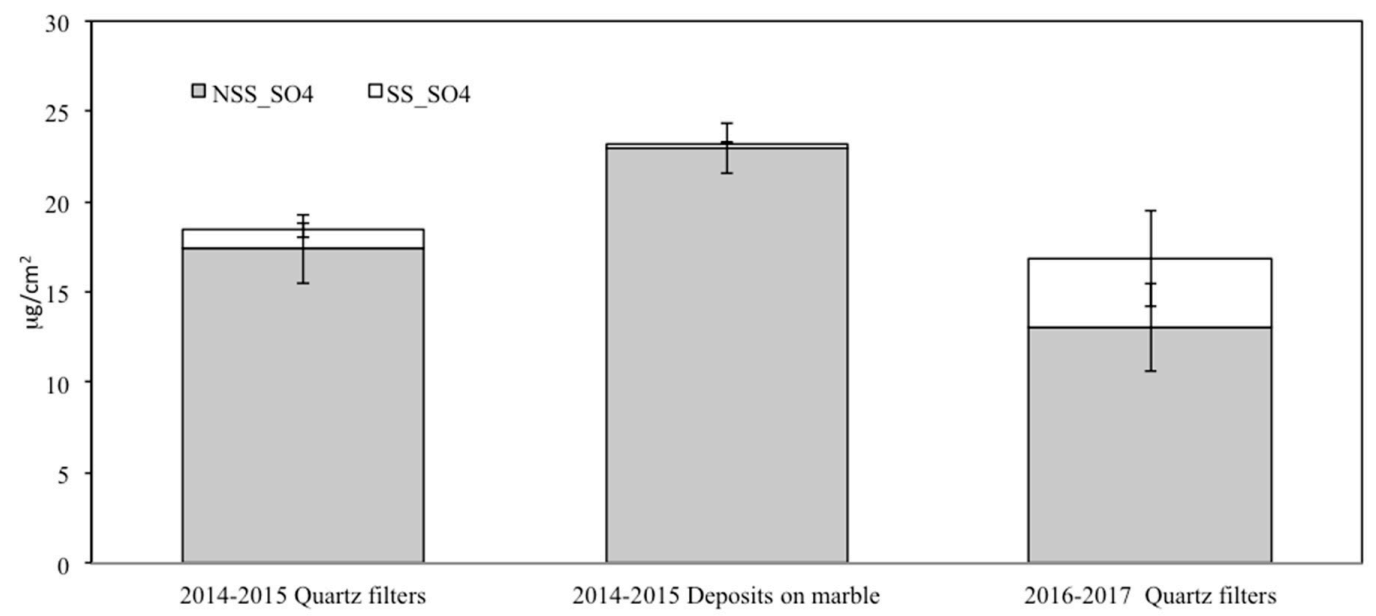

Figure 9. $\mathrm{NSS}_{-} \mathrm{SO}_{4}{ }^{2-}$ (non-sea salt sulphate) and $\mathrm{SS}_{-} \mathrm{SO}_{4}{ }^{2-}$ (sea salt sulphate) contributions determined for quartz fiber filter and deposits on marble specimens in the two exposure periods. 
To support this evaluation, the contribution of sea salt to $\mathrm{Cl}^{-}$concentration has also been calculated for both filters and deposits on marble (Table 3 ) and compared to the characteristic elemental ratios reported for chloride of marine origin $[37,38,41]$. $\mathrm{Cl} / \mathrm{Na}$ ratios lower than the reference value of 1.8 , typical of sea salt, indicate the presence of other sources of $\mathrm{Na}$, in addition to marine spray, such as re-suspended dust.

Table 3. Elemental ratios of interest for the determination of chloride contribution of marine origin calculated for quartz fiber filters and marble specimens exposed on the Duomo façade during the two periods.

\begin{tabular}{cccccc}
\hline & $\mathrm{Cl} / \mathrm{Na}$ & $\mathrm{K} / \mathrm{Na}$ & $\mathbf{M g} / \mathbf{N a}$ & $\mathrm{Ca} / \mathrm{Na}$ & $\mathbf{S O}_{4}{ }^{2-} / \mathbf{N a}$ \\
\hline Marine Origin & 1.80 & 0.04 & 0.12 & 0.04 & 0.25 \\
\hline $\begin{array}{c}\text { Deposits on Marble } \\
\text { July 2014-February 2015 }\end{array}$ & 1.12 & 0.59 & 0.25 & 15.21 & 20.08 \\
\hline $\begin{array}{c}\text { Filter Deposits } \\
\text { July 2014-February 2015 }\end{array}$ & 1.19 & 0.32 & 0.24 & 4.59 & 4.49 \\
\hline $\begin{array}{c}\text { Filter Deposits } \\
\text { July 2016-March 2017 }\end{array}$ & 1.30 & 0.13 & 0.00 & 3.81 & 1.31 \\
\hline
\end{tabular}

Furthermore, $\mathrm{SO}_{4}{ }^{2-} / \mathrm{Na}$ ratios higher than the reference value for sea salt (i.e., 0.25 ), confirm the predominantly anthropogenic origin of sulphates (Table 3). It is also quite interesting comparing $\mathrm{SO}_{4}{ }^{2-} / \mathrm{Cl}$ ratios found in the quartz filters in this study with the typical ratios found in the aerosol particulate matter in the Po Valley [42]. In the case of $\mathrm{PM}_{10}$ this ratio ranges from 3.75 to 5 [27] while in the present study $\mathrm{SO}_{4}{ }^{2-} / \mathrm{Cl}$ ranges from 1 to 3.78 . Such lower values arise from a slightly higher contribution from chloride. This is in accordance with the fact that in the present study the fraction collected on filters is the total suspended particulate matter and chlorides are generally more concentrated in the coarser particles. A possible additional source of sodium chloride during winter may also be due to de-icing treatments.

As regards cations concentrations (Figure 7), calcium is the main species. The higher calcium values registered for the second sampling period could be attributed to dust transport phenomena, which are not unusual in Milan.

Finally, a generally lower concentration of nitrates has been found in the deposits on marble specimens with respect to the quartz filters. Considering the high solubility of nitrates, their concentration on the marble surfaces can be affected by dissolution phenomena and consequently partial migration within the low porous microstructure of the specimens can occur.

In terms of PM deposition rates (DR, calculated as $\mu \mathrm{g} / \mathrm{cm}^{2} \mathrm{month}^{-1}$ ), the values obtained in the present study for quartz filters are in agreement with those obtained for marble surfaces in a study recently carried out in Milan [17]: on average $68.9 \mu \mathrm{g} / \mathrm{cm}^{2} \mathrm{month}^{-1}$ for site 1 and $54.1 \mu \mathrm{g} / \mathrm{cm}^{2} \mathrm{month}^{-1}$ for site 2 against values in the range of about $50-70 \mu \mathrm{g} / \mathrm{cm}^{2} \mathrm{month}^{-1}$ measured in Milan for Carrara marble and quartz filters as surrogate surfaces [17] during the same period of the first exposure test (2014-2015).

As regards marble specimens, DR was $73.2 \mu \mathrm{g} / \mathrm{cm}^{2} \mathrm{month}^{-1}$, slightly higher than the value measured for the quartz filters exposed in parallel in the same site (site 2), i.e., $54.1 \mu \mathrm{g} / \mathrm{cm}^{2} \mathrm{month}^{-1}$, indicating that DR on Candoglia marble is higher with respect to the filter of about $35 \%$.

From the comparison of the overall results of deposits on filters and on marble specimens during the first exposure campaign some considerations can be drawn. As for the deposition rate, the use of filters may lead to an underestimation of the deposition. The same applies for the sulphates, which in the case of marble substrates are generally found in higher concentration with respect to the deposits on filters. As previously discussed, this can also be related to the inherent reactivity of the stone material. As far as the nitrates content are concerned, the generally lower values found on marble 
specimens can be related to decomposition or solubilization mechanisms. In this case, the use of filter may allow a more reliable estimation of the actual content of these species.

In Table 4 OC, and TC concentrations determined for the quartz fiber filters are reported together with their average values. EC values have not been reported since they were below the detection limit of the technique [23]. Due to the very low elemental carbon concentrations OC and TC values are indeed very similar. In Figure 10 average OC, TC and particulate matter concentrations on filters are shown. For both sites higher concentrations have been registered for the second exposure period with the greatest difference detected for site 1 .

Table 4. OC (organic carbon) and TC (total carbon) determined on quartz fiber filters and powder deposits exposed in the two sites on the Duomo façade during the two periods.

\begin{tabular}{|c|c|c|c|}
\hline & & \multicolumn{2}{|c|}{$\mu \mathrm{g} / \mathrm{cm}^{2}$} \\
\hline & & OC & TC \\
\hline \multirow{13}{*}{$\begin{array}{l}\text { Site } 1 \text { Central } \\
\text { terrace } 19.70 \mathrm{~m}\end{array}$} & \multicolumn{3}{|c|}{ July 2014-February 2015} \\
\hline & A1 & 52.67 & 52.71 \\
\hline & $\mathrm{A} 2$ & 56.05 & 56.10 \\
\hline & A3 & 58.05 & 58.09 \\
\hline & A4 & 52.46 & 52.49 \\
\hline & Average & 54.81 & 54.85 \\
\hline & Std dev & 1.42 & 1.42 \\
\hline & \multicolumn{3}{|c|}{ July 2016-March 2017} \\
\hline & B1 & 73.51 & 73.56 \\
\hline & B2 & 77.37 & 77.41 \\
\hline & B3 & 78.74 & 78.77 \\
\hline & Average & 76.54 & 76.58 \\
\hline & Std dev & 1.57 & 1.56 \\
\hline \multirow{15}{*}{$\begin{array}{c}\text { Site } 2 \text { South Pillar } \\
9.40 \mathrm{~m}\end{array}$} & \multicolumn{3}{|c|}{ July 2014-February 2015} \\
\hline & $\mathrm{C} 1$ & 46.46 & 46.49 \\
\hline & $\mathrm{C} 2$ & 48.27 & 48.31 \\
\hline & $\mathrm{C} 3$ & 48.43 & 48.48 \\
\hline & C4 & 44.96 & 45.00 \\
\hline & Average & 47.03 & 47.07 \\
\hline & Std dev & 0.82 & 0.82 \\
\hline & \multicolumn{3}{|c|}{ July 2016-March 2017} \\
\hline & D1 & 58.14 & 58.20 \\
\hline & D2 & 59.41 & 59.46 \\
\hline & D3 & 55.44 & 55.51 \\
\hline & $\mathrm{D} 4$ & 58.79 & 58.86 \\
\hline & D5 & 59.58 & 59.64 \\
\hline & Average & 58.27 & 58.33 \\
\hline & Std dev & 0.67 & 0.67 \\
\hline
\end{tabular}

A good correlation was found between the trend observed for the carbon fraction concentrations (both OC and TC) and the color variations measured on filters (Figure 11). The variation of the $\mathrm{L}^{*}$ coordinate $\left(\Delta \mathrm{L}^{*}\right)$ corresponds to the progressively reduced lightness resulting from particulate matter accumulation, which is also associated to an increase of the $b^{*}$ coordinate $\left(\Delta b^{*}\right)$, due to a slight yellowing effect. After six months of exposure, a significant blackening effect can be detected in all cases, with $\Delta \mathrm{L}^{*}$ values always greater than 11 units. The yellowing effect is less evident and generally ranges between 3.3 (site 2, second exposure period) and 5.3 units (site 1, second exposure period). Moreover, as observed for the carbon fraction trends, the entity of $L^{*}$ and $b^{*}$ variations are more intense during the second exposure period, especially on filters exposed in site 1 . In the present study, as already mentioned, EC values were below the limit of detection and consequently the relationship 
between this specific parameter and the surface color variation cannot be highlighted. Nevertheless, it was possible to observe a relation between the carbonaceous component and the color variation.

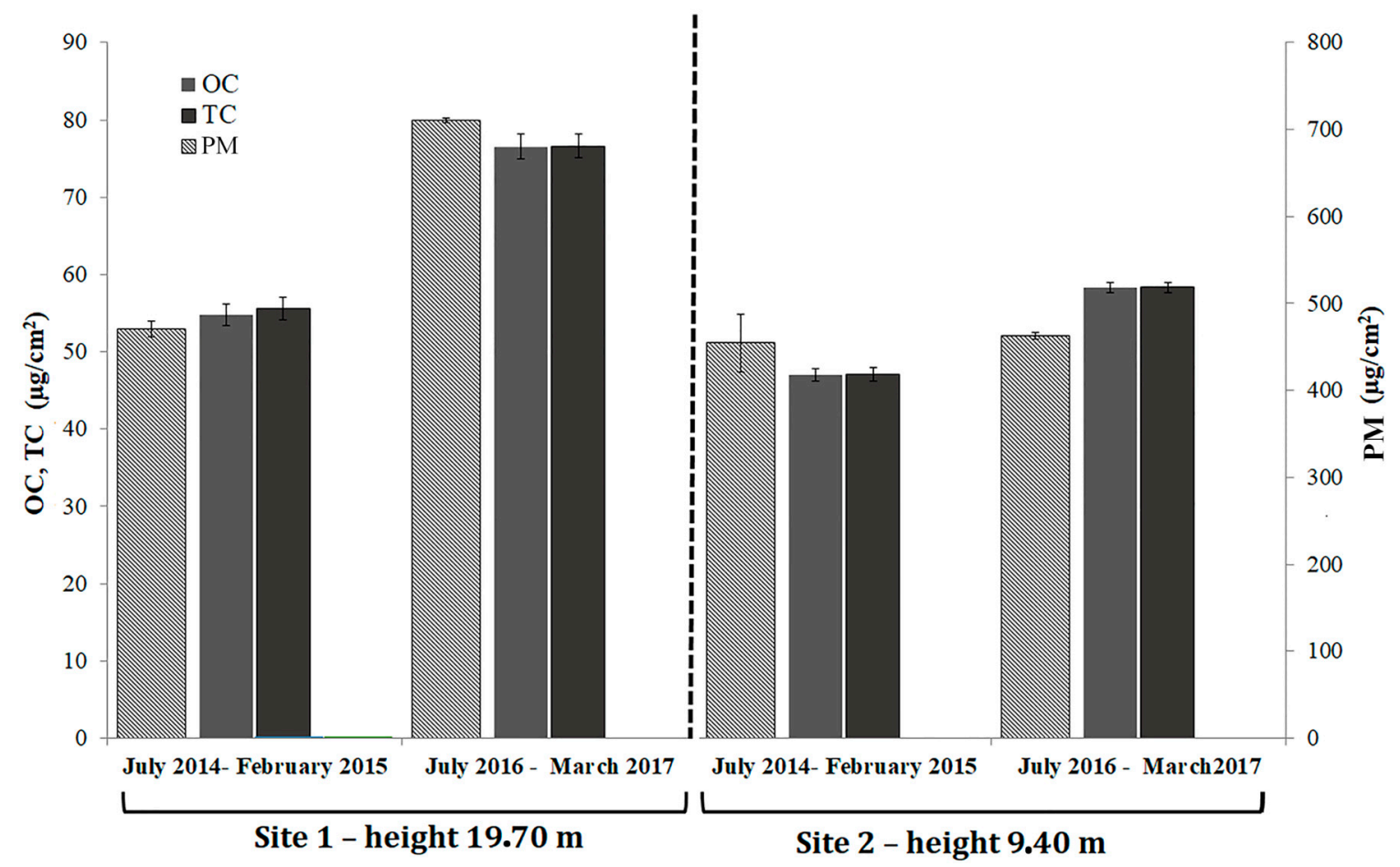

Figure 10. OC (organic carbon), TC (total carbon) and PM weights determined on quartz fiber filters exposed in the two sites on the Duomo façade for two periods.
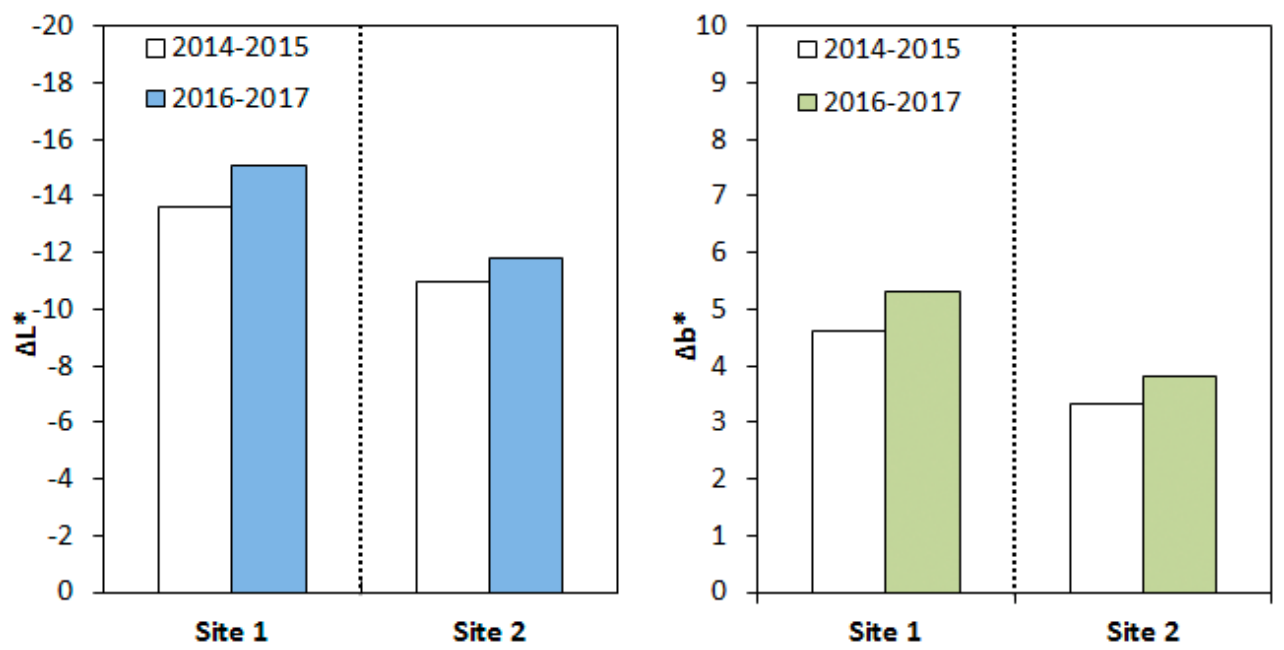

Figure 11. Colorimetric variation of exposed filters: variation of the lightness $\left(\Delta \mathrm{L}^{*}\right.$, left $)$ and of the saturation of the yellow coordinate $\left(\Delta \mathrm{b}^{*}\right.$, right $)$ during the two exposure periods.

In Figure 12 the average concentrations of the major solid and gaseous pollutants (data elaborated from www.arpalombardia.it) are reported for the two periods of interest for the present study, while in Figure 13 nitrate and sulphate average concentrations in deposits on quartz filter exposed on the façade and taking into account both sites are reported. The standard deviations of atmospheric data indicate that the average concentrations of atmospheric pollutants in the two considered periods is rather comparable. A direct correlation between the concentrations of the two precursor (i.e., $\mathrm{NO}_{\mathrm{x}}$ and $\mathrm{SO}_{2}$ ) and the corresponding ions cannot be evidenced: in particular, the remarkable predominance of 
$\mathrm{NO}_{\mathrm{x}}$ over $\mathrm{SO}_{2}$ in atmosphere is not associated to deposits enriched in nitrates. However, it is worth noting that the wet or dry deposition on surfaces is a very complex phenomenon where numerous variables (including, for example, relative humidity) are involved.

Notwithstanding the significant reduction of atmospheric $\mathrm{SO}_{2}$ concentration (Figure 2), the results of the present study show that sulphates are still the main anionic constituents of the deposits on both filters and marble substrates. This is in accordance with studies showing that significant formation of sulphates, as gypsum, can occur even in areas characterized with rather low levels of atmospheric $\mathrm{SO}_{2}$ [7].

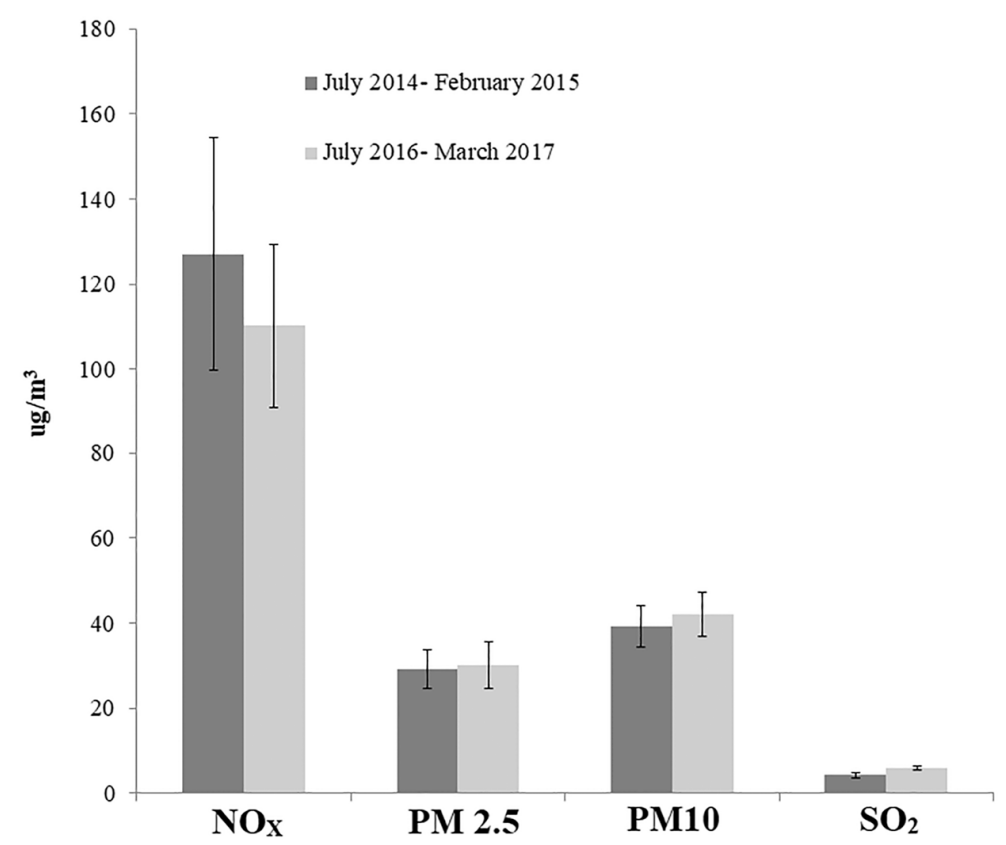

Figure 12. Main pollutants average concentrations for Milan monitoring sites (data from ARPA Lombardia) for the two periods of interest for the exposure field tests.

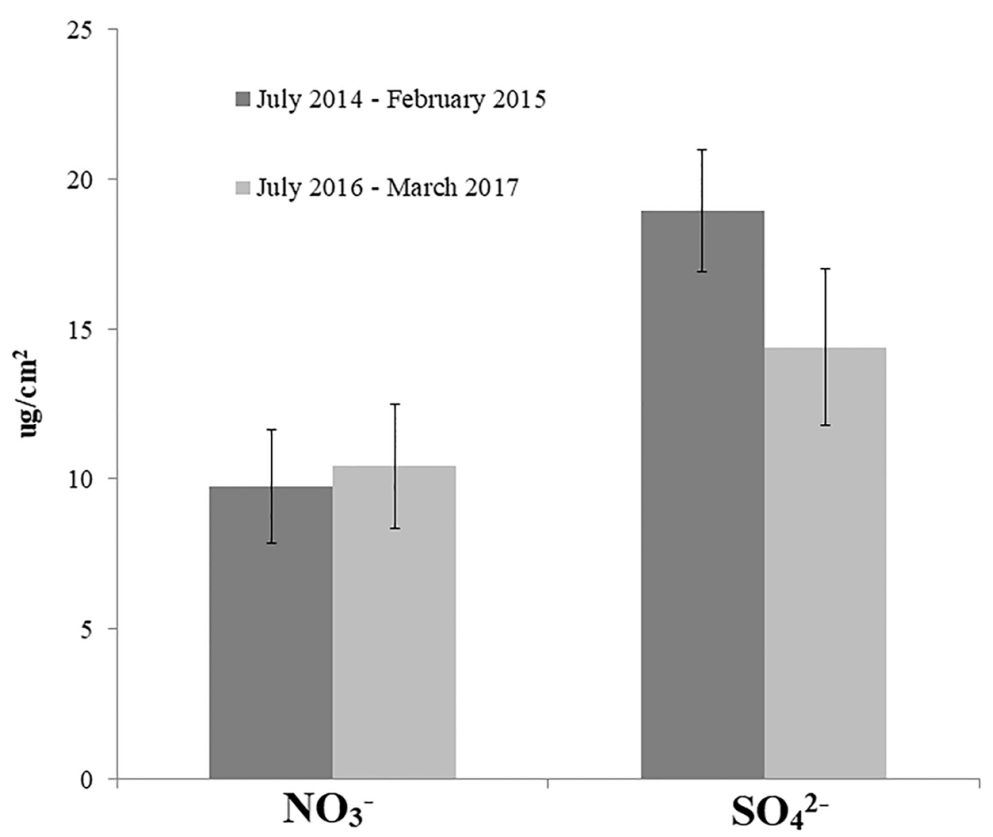

Figure 13. Sulphate and nitrate average concentrations determined on quartz fiber filters for the two periods of interest for the exposure field tests (data calculated as averages between the two sites). 


\section{Conclusions}

In the present research, site exposure tests were carried out between 2014 and 2017 on the main façade of the Milano cathedral for the chemical characterization of the environmental deposition in real exposure conditions (including the quantifications of the main anions and the carbonaceous components). The combined approach exploiting marble and surrogate substrate seems to be a suitable monitoring strategy, although some aspects needs to be pointed out.

As far as PM deposition rate (DR) and sulphates content are considered, it can be observed that in the same site (site 2) they were found to be higher for marble surfaces than for quartz filters. Nitrates, on the other hand, showed an opposite trend. These aspects require further investigation over additional monitoring periods and exposure sites in order to confirm the different response of the stone specimens with respect to the filters. Considering the relevant role of sulphates in stone deterioration, their possible underestimation should be considered if monitoring is conducted by means of filters. Overall, the precise evaluation of DR and deposits composition is fundamental for the definition of effective conservation and mitigation strategies in a rapidly changing environment.

Deposit compositions were compared to the environmental data calculated for the Milan city centre over the same exposure periods. It has to be pointed out that the methodologies of acquisition of environmental data (i.e., based on active atmospheric samplers) are rather different from the passive approach followed in the present work for deposits collection. No direct correlation was found between some atmospheric precursors and their related ions in solid deposits. In particular, a rather stable concentration of environmental nitrogen and sulphur based gas pollutants during the two site exposures was associated to remarkable variations of ions content of the deposits collected on filters in the same periods. This confirms that concentrations of the main pollutants in atmosphere, although relevant in the evaluation of the overall environmental harmfulness, cannot be directly used as proxies to assess the nature of deposits on architectural surfaces exposed in urban contexts.

Considering the historic data of gas pollutants, it was observed that the deposition of sulphates remains consistent despite the significant decreases in atmospheric $\mathrm{SO}_{2}$ recorded in recent years. According to the trends measured by the regional environmental protection agency, PM concentration, on the other hand, does not seem to show a clear decrease. Given its correlation with the deposition of carbonaceous particles, thus affecting soiling, its actual role on exposed surfaces should be further monitored.

Author Contributions: Conceptualization and methodology, P.F., S.G., D.G. and L.T.; Investigation, V.C., P.F. and D.G.; Visualization, V.C., P.F., S.G. and D.G.; Writing-original draft preparation, P.F. and D.G.; Writing-review and editing, P.F., S.G. and D.G.

Funding: This research has been carried out in the framework of the project "La Facciata del Duomo di Milano. Piano di monitoraggio e conservazione programmata a seguito dell'intervento straordinario di restauro" funded by Veneranda Fabbrica del Duomo di Milano.

Acknowledgments: The authors wish to acknowledge Veneranda Fabbrica del Duomo di Milano and Ing. Francesco Canali for the support and collaboration during the activity.

Conflicts of Interest: The authors declare no conflicts of interest.

\section{References}

1. Watt, J.; Tidblad, J.; Kucera, V.; Hamilton, R. The Effect of Air Pollution on Cultural Heritage; Watt, J., Ed.; Springer-Verlag: Berlin, Germany, 2009; ISBN 978-0-387-84892-1.

2. Camuffo, D.; Del Monte, M.; Sabbioni, C. Origin and growth mechanisms of the sulfated crusts on urban limestone. Water Air Soil Pollut. 1982, 19, 351-359. [CrossRef]

3. Del Monte, M.; Sabbioni, C.; Vittori, O. Urban stone sulphation and oil-fired carbonaceous particles. Sci. Total Environ. 1984, 36, 369-376. [CrossRef]

4. Sabbioni, C. Contribution of atmospheric deposition to the formation of damage layers. Sci. Total Environ. 1995, 167, 49-55. [CrossRef] 
5. Steiger, M.; Charola, A.E.; Sterflinger, K. Weathering and deterioration. In Stone in Architecture; Siegesmund, S., Snethlage, R., Eds.; Springer: Berlin, Germany, 2011; pp. 225-313.

6. Rodriguez-Navarro, C.; Sebastian, E. Role of particulate matter from vehicle exhaust on porous building stones (limestone) sulfation. Sci. Total Environ. 1996, 187, 79-91. [CrossRef]

7. Török, A.; Licha, T.; Simon, K.; Siegesmund, S. Urban and rural limestone weathering; the contribution of dust to black crust formation. Environ. Earth Sci. 2011, 63, 675-693. [CrossRef]

8. Gibeaux, S.; Vázquez, P.; Kock, T.; De Cnudde, V.; Thomachot-Schneider, C. Weathering assessment under X-ray tomography of building stones exposed to acid atmospheres at current pollution rate. Constr. Build. Mater. 2018, 168, 187-198. [CrossRef]

9. Viles, H.A.; Taylor, M.P.; Yates, T.J.S.; Massey, S.W. Soiling and decay of N. M. E. P. limestone tablets. Sci. Total Environ. 2002, 292, 215-229. [CrossRef]

10. Grossi, C.M.; Esbert, R.M.; Dã, F.; Alonso, F.J. Soiling of building stones in urban environments. Build. Environ. 2003, 38, 147-159. [CrossRef]

11. Urosevic, M.; Yebra-Rodríguez, A.; Sebastián-Pardo, E.; Cardell, C. Black soiling of an architectural limestone during two-year term exposure to urban air in the city of Granada (S Spain). Sci. Total Environ. 2012, 414, 564-575. [CrossRef] [PubMed]

12. Ghedini, N.; Ozga, I.; Bonazza, A.; Dilillo, M.; Cachier, H.; Sabbioni, C. Atmospheric aerosol monitoring as a strategy for the preventive conservation of urban monumental heritage: The Florence Baptistery. Atmos. Environ. 2011, 45, 5979-5987. [CrossRef]

13. Watt, J.; Tidblad, J.; Kucera, V.; Hamilton, R. Monitoring, modelling and mapping. In The Effects of Air Pollution on Cultural Heritage; Hamilton, R., Kucera, V., Tidblad, J., Watt, J., Eds.; Springer: Berlin, Germany, 2009; pp. 29-51.

14. Zappia, G.; Sabbioni, C.; Riontino, C.; Gobbi, G.; Favoni, O. Exposure tests of building materials in urban atmosphere. Sci. Total Environ. 1998, 224, 235-244. [CrossRef]

15. Viles, H.A.; Gorbushina, A.A. Soiling and microbial colonisation on urban roadside limestone: A three year study in Oxford, England. Build. Environ. 2003, 38, 1217-1224. [CrossRef]

16. Comite, V.; De Buergo, M.Á.; Barca, D.; Belfiore, C.M.; Bonazza, A.; La Russa, M.F.; Pezzino, A.; Randazzo, L.; Ruffolo, S.A. Damage monitoring on carbonate stones: Field exposure tests contributing to pollution impact evaluation in two Italian sites. Constr. Build. Mater. 2017, 152, 907-922. [CrossRef]

17. Ferrero, L.; Casati, M.; Nobili, L.; Angelo, L.D.; Rovelli, G.; Sangiorgi, G.; Rizzi, C.; Perrone, M.G.; Sansonetti, A.; Conti, C.; et al. Chemically and size-resolved particulate matter dry deposition on stone and surrogate surfaces inside and outside the low emission zone of Milan: Application of a newly developed Deposition Box. Environ. Sci. Pollut. Res. 2018, 25, 9402-9415. [CrossRef] [PubMed]

18. Morlin Visconti Castiglione, B. Alcune note sui lavori di restauro della facciata del Duomo, 2003-2008. In Nuovi Annali-Rassegna di Studi e Contributi per il Duomo di Milano; Edizioni Et: Milano, Italy, 2008.

19. Toniolo, L.; Zerbi, C.M.; Bugini, R. Black layers on historical architecture. Environ. Sci. Pollut. Res. 2009, 16, 218-226. [CrossRef] [PubMed]

20. UNI 10859. Cultural Heritage-Natural Stones—Determination of Water Absorption by Capillarity; Ente Nazionale Italiano di Unificazione: Milan, Italy, 2000.

21. UNI-EN 15886. Conservation of Cultural Property—Test Methods—Colour Measurement of Surfaces; Ente Nazionale Italiano di Unificazione: Milan, Italy, 2010.

22. Fermo, P.; Turrion, R.G.; Rosa, M.; Omegna, A. A new approach to assess the chemical composition of powder deposits damaging the stone surfaces of historical monuments. Environ. Sci. Pollut. Res. 2015, 22, 6262-6270. [CrossRef] [PubMed]

23. Piazzalunga, A.; Bernardoni, V.; Fermo, P.; Vecchi, R. Optimisation of analytical procedures for the quantification of ionic and carbonaceous fractions in the atmospheric aerosol and applications to ambient samples. Anal. Bioanal. Chem. 2013, 405, 1123-1132. [CrossRef] [PubMed]

24. La Russa, M.F.; Fermo, P.; Comite, V.; Belfiore, C.M.; Barca, D.; Cerioni, A.; De Santis, M.; Barbagallo, L.F.; Ricca, M.; Ruffolo, S.A. The Oceanus statue of the Fontana di Trevi (Rome): The analysis of black crust as a tool to investigate the urban air pollution and its impact on the stone degradation. Sci. Total Environ. 2017, 593, 297-309. [CrossRef] [PubMed]

25. Fermo, P.; Piazzalunga, A.; Vecchi, R.; Valli, G.; Ceriani, M. A TGA/FT-IR study for measuring OC and EC in aerosol samples. Atmos. Chem. Phys. 2006, 6, 255-266. [CrossRef] 
26. Panteliadis, P.; Hafkenscheid, T.; Cary, B.; Diapouli, E.; Fischer, A.; Favez, O.; Quincey, P.; Viana, M.; Hitzenberger, R.; Vecchi, R.; et al. ECOC comparison exercise with identical thermal protocols after temperature offset correction-Instrument diagnostics by in-depth evaluation of operational parameters. Atmos. Meas. Tech. 2015, 8, 779-792. [CrossRef]

27. Bigi, A.; Bianchi, F.; De Gennaro, G.; Di Gilio, A.; Fermo, P.; Ghermandi, G.; Prévôt, A.S.H.; Urbani, M.; Valli, G.; Vecchi, R.; et al. Hourly composition of gas and particle phase pollutants at a central urban background site in Milan, Italy. Atmos. Res. 2017, 186, 83-94. [CrossRef]

28. Bernardoni, V.; Elser, M.; Valli, G.; Valentini, S.; Bigi, A.; Fermo, P.; Piazzalunga, A.; Vecchi, R. Size-segregated aerosol in a hot-spot pollution urban area: Chemical composition and three-way source apportionment. Environ. Pollut. 2017, 231, 601-611. [CrossRef] [PubMed]

29. Bernardoni, V.; Vecchi, R.; Valli, G.; Piazzalunga, A.; Fermo, P. PM 10 source apportionment in Milan (Italy) using time-resolved data. Sci. Total Environ. 2011, 409, 4788-4795. [CrossRef] [PubMed]

30. Algieri, A.; Chiesa, M.; Cigolini, G.; Colombi, C.; Cosenza, R.; Cuccia, E.; Dal Santo, U.; Dal Zotto, M.; Ferrari, R.; Gentile, N.; et al. Rapporto Sulla Qualità Dell' Aria Della Città Metropolitana di Milano; ARPA Lombardia: Milan, Italy, 2014.

31. Algieri, A.; Chiesa, M.; Cigolini, G.; Colombi, C.; Cosenza, R.; Cuccia, E.; Dal Santo, U.; Dal Zotto, M.; Ferrari, R.; Gentile, N.; et al. Rapporto Sulla Qualità Dell' Aria Della Città Metropolitana di Milano; ARPA Lombardia: Milan, Italy, 2015. Available online: http:/ / www.arpalombardia.it/qariafiles/RelazioniAnnuali / RQA_MI_2015.pdf (accessed on 14 September 2018).

32. Algieri, A.; Chiesa, M.; Cigolini, G.; Colombi, C.; Cosenza, R.; Cuccia, E.; Dal Santo, U.; Dal Zotto, M.; Ferrari, R.; Gentile, N.; et al. Rapporto Sulla Qualità Dell' Aria Della Città Metropolitana di Milano; ARPA Lombardia: Milan, Italy, 2016. Available online: http:/ / www.arpalombardia.it/qariafiles/RelazioniAnnuali/ RQA_MI_2016.pdf (accessed on 14 September 2018).

33. Pedrazzani, R.; Alessandri, I.; Bontempi, E.; Cappitelli, F.; Cianci, M.; Pantos, E.; Toniolo, L.; Depero, L.E. Study of sulphation of Candoglia marble by means of micro X-ray diffraction experiments. Appl. Phys. A Mater. Sci. Process. 2006, 83, 689-694. [CrossRef]

34. Bonazza, A.; Sabbioni, C.; Ghedini, N. Quantitative data on carbon fractions in interpretation of black crust and soiling on European built heritage. Atmos. Environ. 2005, 39, 2607-2608. [CrossRef]

35. Auras, M.; Bundschuh, P.; Eichhorn, J.; Kirchner, D.; Mach, M.; Seewald, B.; Snethlage, R. Salt deposition and soiling of stone facades by traffic-induced immissions. Environ. Earth Sci. 2018, 77, 1-16. [CrossRef]

36. Quang, T.N.; He, C.; Morawska, L.; Knibbs, L.D.; Falk, M. Vertical particle concentration profiles around urban office buildings. Atmos. Chem. Phys. 2012, 12, 5017-5030. [CrossRef]

37. Karthikeyan, S.; Balasubramanian, R. Determination of water-soluble inorganic and organic species in atmospheric fine particulate matter. Microchem. J. 2006, 82, 49-55. [CrossRef]

38. Keene, W.C.; Pszenny, A.A.P.; Galloway, J.N.; Hawley, M.E. Sea-salt corrections and interpretation of constitutent ratios in marine precipitation. J. Geophys. Res. 1986, 91, 6647-6658. [CrossRef]

39. La Russa, M.F.; Comite, V.; Aly, N.; Barca, D.; Fermo, P.; Rovella, N.; Antonelli, F.; Tesser, E.; Aquino, M.; Ruffolo, S.A. Black crusts on Venetian built heritage, investigation on the impact of pollution sources on their composition. Eur. Phys. J. Plus 2018, 133, 370. [CrossRef]

40. Atzei, D.; Fermo, P.; Vecchi, R.; Fantauzzi, M.; Comite, V.; Valli, G. Composition and origin of $\mathrm{PM}_{2.5}$ in Mediterranean countryside. Environ. Pollut. 2018, in submission.

41. Seinfeld, J.H.; Pandis, S.N. Atmospheric Chemistry and Physics; Wiley: New York, NY, USA, 1998.

42. Colombi, C. Relazione Campagna PoAIR Febbraio 2014. Available online: http://www. arpalombardia.it/qariafiles/varie/Relazione\%20campagna\%20PoAIR\%20febbraio\%202014.pdf (accessed on 14 September 2018).

(C) 2018 by the authors. Licensee MDPI, Basel, Switzerland. This article is an open access article distributed under the terms and conditions of the Creative Commons Attribution (CC BY) license (http://creativecommons.org/licenses/by/4.0/). 